\title{
PREZENTAEJE
}

\section{Kierunki badań w Zakładzie Historii Nauki, Oświaty i Wychowania Instytutu Pedagogiki Uniwersytetu Gdańskiego w latach 1953 - 2001*}

W okresie powojennym nie bylo w Gdańsku typowego środowiska historyków wychowania i w zasadzie do połowy lat 50 nie ukazały sie tu ważniejsze prace poświęcone interesującej nas problematyce. Dopiero inspiracje wynikające z przebiegu obrad zorganizowanej w 1954 r. w Gdańsku Konferencji Pomorskiej PAN przyczyniły się z czasem do pełniejszego uświadomienia sobie roli kultury umysłowej całego nadmorskiego regionu $w$ minionych stuleciach. Do 1953 r. nie opublikowano w Gdańsku bardziej znaczacych prac związanych z dziejami oświaty. Za początek właściwych badań należy zatem uznać rezultaty obrad wspomnianej Konferencji Pomorskiej PAN. W wyniku jej postanowień starano się wypracować podstawowe założenia metodologiczne, ustalić stan zasobów archiwalnych i zebrać efekty dotychczasowych opracowań, dotyczących sytuacji gdańskiego szkolnictwa na przestrzeni wieków. Można tu odnotować zapoczątkowanie dociekań obejmujących okres od Odrodzenia do współczesności.

W poszukiwaniach gdańszczan od początku utrwalił się wyraźny podział chronologiczny, tematyczny i terytorialny. Analiza zawartości pierwszych powojennych publikacji pozwala wyodrębnić dwa podstawowe nurty różniące się głównie zasięgiem i czasokresem poruszanych zagadnien. Reprezentanci pierwszego skupili się na wydarzeniach z przeszlości Gdańska w okresie staropolskim, zaś drugiego nurtu - na wiekach XIX i XX, wkraczajac przy tym wielokrotnie na teren całego Pomorza. Początek drugiego nurtu badań nad oświata XIX i XX w., łączy się z referatem $K$. Trzebiatowskiego wygłoszonym na Konferen- cji Pomorskiej PAN a poświęconym szkolnictwu na Pomorzu ${ }^{1}$. $Z$ biegiem lat utrwalał się coraz wyraźniej dwubiegunowy podział zairteresowań badawczych, co wynikało $w$ znacznej mierze $\mathrm{z}$ różnic $\mathrm{w}$ podejściu metodologicznym do poruszanych zagadnień.

Powołanie Uniwersytetu Gdańskiego w 1970 roku i utworzenie Wydziału Humanistycznego doprowadziło do powstania Instytutu Pedagogiki i Psychologii, zaś w jego strukturze Zakładu Historii Nauki, Oświaty i Wychowania kierowanego przez prof. Kazimierza Kubika (w miejsce wcześniej istniejącej Katedry Historii Oswiaty i Wychowania działającej na gdańskiej WSP). Całokształt wydanych wtedy publikacji dobrze ilustruje ów podział zainteresowań naukowych na dwa wyraźne podokresy chronologiczne: czasy przedrozbiorowe oraz dzieje szkolnictwa w XIX i XX w. Równocześnie pogłębiło się zróżnicowanie tematyczne, wynikające $\mathrm{z}$ koncentracji części osób na problematyce oświatowej w Gdańsku i Prusach Królewskich, zaś pozostałych na kształtowaniu się spraw wychowawczych na Pomorzu w granicach powojennej Polski. Zainteresowano się także zagadnieniami $\mathrm{z}$ zakresu organizacji i zarządzania oświata ${ }^{2}$.

Nurt pierwszy skoncentrował się na dziejach Gdańskiego Gimnazjum Akademickiego oraz na dorobku naukowym i literackim jego dawnych profesorów. Szczególnie skupiono się na rozwoju dyscyplin humanistycznych (m.in. retoryki i historii), prawnych, językach orientalnych i medycynie. Budzily się zainteresowania osiagnięciami dziejopisarstwa, nauk ścisłych i znaczeniem szkolnictwa prywatnego ${ }^{3}$. 
Drugi nurt, związany $\mathrm{z}$ czasami nowszymi, także znacznie poszerzył krag omawianych problemów. Przede wszystkim należy wymienić dalsze dociekania dotyczace tradycji oświatowych na Pomorzu, zwalczania analfabetyzmu, rozwoju czytelnictwa wśród warstw niższych. Podkreślano rolę miejscowej ludności, w tym Kaszubów, w przeciwstawianiu się germanizacji. Naświetlono zasługi prasy, organizacji polonijnych i wybitnych działaczy w podtrzymywaniu ducha narodowego, nie pomijano też integrującego oddziaływania strajków szkolnych w latach $1906-1907^{4}$. Zajmowano się też historią poszczególnych szkół. Należy także odnotować fakt rozszerzenia badań aż po czasy współczesne. Przypomniano między innymi sylwetki wielce zasłużonych nauczycieli i działaczy polonijnych ${ }^{5}$. Ukazała się także monografia poświęcona szkolnictwu powszechnemu w Polsce przed reformą Jędrzejewicza ${ }^{6}$. Nowym zagadnieniem zapoczątkowanym w latach sześćdziesiatych były dzieje wychowania i szkolnictwa morskiego. Ten nurt badań łączył się z przygotowaniami do obchodów 400 rocznicy powolania Komisji Morskiej przez Zygmunta Augusta ${ }^{7}$. Ponadto interesowano się oświatą muzyczna, działalnością instytucji artystycznych oraz ich więzia $\mathrm{z}$ wychowaniem patriotycznym w minionych dziesięcioleciach ${ }^{8}$.

W latach 1960-1970, znacznie wzbogaciła i zróżnicowała się tematyka badań z zakresu dziejów nauki i szkolnictwa. Wzrosła liczba uczonych, którzy podejmowali te zagadnienia, co ułatwiło zacieśnienie wspólpracy i wymianę poglądów. Zwiększenie efektywności badań z dziedziny historii wychowania, przyczynilo się do stworzenia pomyślnego klimatu dla rozwoju tej dyscypliny w nowo utworzonym Uniwersytecie Gdańskim?

Od 1971 roku Zakład Historii Nauki, Oświaty $\mathrm{i}$ Wychowania rozpoczał prace $w$ strukturze nowo powstałego Uniwersytetu Gdańskiego. Nastapiło dalsze wzbogacenie poruszanej problematyki oraz zintensyfikowanie poszukiwań badawczych. Niestety nadal pomijano okres średniowiecza, natomiast skupiono się na określeniu roli gimnazjum akademickiego $w$ dobie Odrodzenia i Baroku. Żywo interesowano się także nauczaniem różnych przedmiotów z filozofia, geografia, matematyka, prawem, historia, naukami filologicznymi i przyrodniczymi na czele. Niektóre dy- scypliny doczekały się osobnych rozpraw $\mathrm{z}$ uwzględnieniem m.in. dorobku wybranych profesorów: B. Keckermanna, J. Pastoriusa, J. Hoppego, G. Lengnicha, J. Schultza-Szuleckiego $\mathrm{i}$ in. ${ }^{10}$ Kontynuowano też badania nad gdańska historiografia mieszczańska doby Baroku i jej związkami ze szkolnictwem. Z oświata łącza się studia poświęcone różnym dyscyplinom nauki ${ }^{11}$. Wznowiono ponadto rozważania nad dziejami wychowania morskiego $\mathrm{w}$ powiązaniu $\mathrm{z}$ historia Prus Królewskich i całej Rzeczypospolitej ${ }^{12}$. Nadto prowadzono badania na temat poziomu kultury umysłowej, znaczenia gimnazjów akademickich, peregrynacji akademickich, wychowania artystycznego i recepcji poglądów wybitnych uczonych, jak chociażby J.A. Komeńskiego ${ }^{13}$. Wartościowe syntezy dziejów nauki gdańskiej w okresie I Rzeczypospolitej przyniosly poszczególne tomy Historii nauki polskiej i odpowiednie części Historii Pomorza i Historii Gdańska.

W badaniach odnoszacych się do XIX i XX wieku, a prowadzonych od lat siedemdziesiatych także można stwierdzić znaczny postęp. Analizowano tu miejsce języka polskiego w ówczesnych szkołach, podręczniki i czasopisma przeznaczone dla uczniów, działalność tajnych organizacji istnjejacych $w$ gimnazjach, zasługi polskich stowarzyszeń kulturalno-społecznych $w$ upowszechnianiu kształcenia na poziomie elementarnym ${ }^{14}$. Pracownicy Zakładu pogłębiali zainteresowania odnoszące się do lat wojny i okupacji, przebiegu tajnego nauczania, wysilków podejmowanych po zakończeniu wojny na rzecz odbudowy szkolnictwa i wyrównywania szans młodzieży powracającej $\mathrm{z}$ frontu, charakteryzowano pracę nauczycieli i formy ich dokształcania, opracowywano szkice poświęcone poszczególnym placówkom, w tym służącym wychowaniu morskiemu ${ }^{15}$. Opublikowano też liczne studia na temat organizacji szkolnictwa oraz skrypty porównujące system szkolny w Polsce $z$ systemami w innych państwach, uzupełnieniem tych zagadnień były wydawnictwa o charakterze źródłowym ${ }^{16}$. W omawianych latach zwiększyła się liczba prac odnoszących się do wychowania artystycznego, zwłaszcza muzycznego ${ }^{17}$.

W 1983 r. w Gdańsku została zorganizowana okolicznościowa konferencja, podsumowująca stan badań nad oświatą i nauką Pomorza Gdańskiego. Konferencja zwiazana była także z przejściem 
na emeryturę prof. Klemensa Trzebiatowskiego. Obrady pod hasłem Wktad Pomorza Gdańskiego do rozwoju nauki $i$ oświaty zgromadziły liczne grono uczonych, potwierdzając, iż temat budził w kraju stosunkowo duże zainteresowanie. Wygłoszone referaty i opinie uwydatniły najpilniejsze potrzeby badawcze, które starano się realizować po $1983 \mathrm{r}$.

Rozwój kadry Zakładu Historii Nauki, Oświaty i Wychowania, który na przełomie lat 1970/1980 zatrudniał czterech samodzielnych pracowników, oddziaływał pomyślnie na ustabilizowanie się jego miejsca wśród placówek prowadzacych w Polsce analogiczne badania. Niestety w 1984 r., kilka miesięcy po przejściu na emeryturę, zmarł kierujacy Zakładem od 1980 r. prof. Klemens Trzebiatowski, w 1986 r. prof. Kazimierz Kubik, który od 1980 r. przebywał na emeryturze, rok później doc. Wiktor Frąckowiak, a w 1987 r. na emeryturę przeszedł dr Jerzy Szews. Nie pozostało to bez wpływu na intensywność i rozległość, i jakość prowadzonych dotąd badań.

Od połowy lat osiemdziesiatych nadal zachowana została dwutorowa specyfika chronologiczna. Należy jednak odnotować w Zakładzie zauważalną zmianę pokoleniowa, której efektem stał się wybór częściowo nowej problematyki badawczej. Podjęto prace porównawcze obejmujące różne typy szkół działające w Prusach Królewskich, próbując omawiać ich zasługi na tle ówczesnego dorobku nauki i oświaty europejs$\mathrm{kiej}^{18}$. Zintensyfikowano też poszukiwania syntetyzujące dotychczasowa wiedzę na temat peregrynacji akademickich młodzieży pomorskiej a także znaczenia wymiany doświadczeń wychowawczych i dydaktycznych oraz przeszłości poszczególnych placówek szkolnych ${ }^{19}$.

W ostatnich latach pracownicy Zakładu Historii Nauki, Oświaty i Wychowania wyraźnie skoncentrowali swoje wysiłki badawcze na zagadnieniu kształtowania się nauczania historii w szkolnictwie protestanckim i katolickim różnych krajów. Omówiono miejsce wiedzy historycznej w programach wielu placówek europejskich do schylku Odrodzenia. Ukazano rozwiazania programowe istniejace $w$ kolegiach jezuickich $i$ pijarskich oraz $w$ zakładach protestanckich w I Rzeczypospolitej. Zainteresowanie historia w programach szkolnych do końca XVIII w. stało się charakterystyczna cechą badań kontynuowanych przez gdańskich historyków wychowania reprezentujacych różne pokolenia ${ }^{20}$.

W latach dziewięćdziesiątych dociekania te wzbogacono i rozszerzono o monografie poszczególnych kolegiów, analizy reform programowych w calym szkolnictwie okresu przedrozbiorowego oraz szlacheckich i mieszczańskich modeli wychowania XVI - XVIII w., jak również o refleksje na temat ideałów wychowania realizowanych w placówkach zakonnych starających się być miejscem kształcenia przyszłych elit politycznych Rzeczypospolitej szlacheckiej. Stało się to możliwe dzięki wspólpracy $\mathrm{z}$ uczelniami wyższymi w kraju i zagranica, Instytutem Historii Nauki PAN, polskimi prowincjami jezuitów i pijarów, kierownictwami licznych archiwów polskich i zagranicznych. Przejawem zainteresowań badaczy ośrodka gdańskiego sa także publikacje typu biograficznego i bibliograficznego, omawiające dorobek naukowy uczonych reprezentujących różne dziedziny wiedzy ${ }^{21}$.

Drugi nurt badań prowadzonych w Gdańsku, poświęcony czasom nowszym nadal utrzymuje podstawowe kierunki swoich zainteresowań. Zajmując się czasami zaborów, skupiano się zwykle na oświacie w II połowie XIX i początkach XX wieku. Omawiano znaczenie wydanych w języku polskim książek i czasopism. Uwage poświęcano nadto miejscu języka narodowego $w$ programach nauczania, przebiegowi strajków szkolnych, pracy tajnych organizacji młodzieżowych, rozwojowi szkolnictwa na Pomorzu w różnych okresach ${ }^{22}$. Ukazała się też praca o uniwersytetach w Polsce w XIX w. ${ }^{23}$

Prowadzono także badania odnoszące się do oceny sytuacji w czasach po II wojnie światowej. Wstępne podsumowanie dotychczasowego stanu wiedzy na ten temat przyniosła sesja zorganizowana w 1986 r. przez Ośrodek Doskonalenia Nauczycieli przy współpracy Zakładu Historii Nauki, Oświaty i Wychowania ${ }^{24}$.

W ostatnich latach uwaga badaczy gdańskiego ośrodka nadal koncentruje się wokół zagadnień związanych z historią wybranych placówek oświatowych. Nie zaniedbano również kwestii odnoszacych się do problematyki form kształcenia $\mathrm{i}$ doskonalenia nauczycieli $\mathrm{w}$ regionie $\mathrm{i}$ całym kraju, pracy uczelni wyższych oraz placówek artystycznych ${ }^{25}$. Przy wszechstronnej współpracy 
krajowej i międzynarodowej analizuje się znaczenie podejmowanych po 1989 r. reform oświatowych $w$ Polsce, a także porównuje się nasz system edukacji $\mathrm{z}$ systemami obowiazujacymi w innych krajach, zwlaszcza w Szwecji ${ }^{26}$.

Potwierdzeniem bardzo żywych kontaktów naukowych i ścisłej współpracy badawczej Zakładu Historii Nauki, Oświaty i Wychowania $\mathrm{z}$ większością ośrodków akademickich w Polsce była zorganizowana w maju 1996 r. sesja pt. Historia-Edukacja. Sesja związana z jubileuszem pracy naukowej i dydaktycznej profesora Lecha Mokrzeckiego zgromadziła reprezentantów niemal wszystkich uczelni i pokrewnych instytucji naukowych w kraju. Teksty referatów i omówienie obrad opublikowano w I tomie Ars Educandi, znalazły one swe odzwierciedlenie także w licznych periodykach ${ }^{27}$.

Podsumowując należy stwierdzić, że w całym okresie powojennym grono gdańskich historyków wychowania zaliczalo się do szczególnie czynnych uczestników wielu konferencji krajowych i międzynarodowych ${ }^{28}$. Opublikowali oni wiele różnorodnych prac związanych z zagadnieniami szeroko rozumianej historii oświaty i nauki ,uczestniczac w przywracaniu kulturze trwałej wartości jaka jest tradycja.

\section{Jacek Taraszkiewicz}

* Artykuł w znacznej mierze opiera się na wynikach badań przeprowadzonych przez Lecha Mokrzeckiego, opublikowanych w dwóch rozprawach: Wspótczesne kierunki badań nad dziejami oświaty i nauki $w$ środowisku gdaniskim $i$ ich najnowsze wyniki [w:] Historia wychowania w XX wieku. Dorobek i perspektywy, pod red. T. Gumuly, J. Krasuskiego, S. Majewskiego, Kielce 1998, s. 515-525: Historia wychowania w Gdańsku z perspektywy pięćdziesięciolecia (1946-1996), „Ars Educandi”, 2000, t. II, s. 19-33.

${ }^{1}$ K. Trzebiatowski, Szkolnictwo $i$ oświata polska na ziemiach Pomorza Zachodniego w okresie międzywojennym (1918 - 1939), [w:] Konferencja Pomorska PAN, Warszawa 1959.

${ }^{2}$ K. Trzebiatowski, Organizacja $i$ podstawy prawhe szkolnictwa, t. I-IV, Gdańsk 1964 - 1969.

${ }^{3}$ K. Kubik, Polska szkota prywatna $w$ dawnym Gdańsku, Gdańsk 1963; K. Kubik, L. Mokrzecki, Trzy wieki nauki gdanskiej. Szkice z dziejów XVI-XVIII wieku, Gdańsk 1969.

${ }^{4}$ K. Kubik, Walka o szkole polska $w$ Wolnym Mieście Gdańsku, „Pomorze Gdańskie" 1965, nr 1, K. Trzebiatowski, Prasa i organizacje polskie w rejencji gdańskiej na przelomie XIX i XX wieku, „Rocznik Gdański" 1969, t. 27; tegoż, Szkolnictwo oraz polska dzialalność oświatowo-kulturalna na Powiślu w latach 1918-1932, „Przeglad Historyczno-Oświatowy” 1968, nr 2.

5 J. Szews, Nauczanie języka polskiego w szkolach gdańskich XIX wieku, „Przegląd Historyczno-Oswiatowy" 1964, nr 3; Zob. też Polski Slownik Biograficzny i serię wydawnicza „Pomorze Gdańskie".

${ }^{6}$ K. Trzebiatowski, Szkolnictwo powszechne w Polsce w latach 1918-1932, Wrocław 1970.

7 Por. K. Kubik, Szkolnictwo morskie w Polsce w XVI-XVIII w., w: Materialy z Sesji Komisji Morskiej, Warszawa 1969; tegoż. Szkolnictwo morskie w Polsce (1947-1967), Rybolówstwo morskie, „Gdańskie Zeszyty Humanistyczne. Prace Pomorzoznawcze" 1969, 18.

8 Tenże, Stowo i pieśń w walce o polskość Pomorza Gdańskiego na przelomie XIX i XX wieku. Gdańsk 1962; L. Mokrzecki, Polskie Konserwatorium Muzyczne w Gdańsku (1929-1939), „Gdańskie Zeszyty Humanistyczne. Prace Pomorzoznawcze" 1966, 13

9 L. Mokrzecki, Poczatki, rozwój i perspektywy Uniwersytetu Gdańskiego, „Rocznik Gdański”, t. 54, 1994 , z. 2.

${ }^{10}$ K. Kubik, Joachim Pastorius gdański pedagog XVII wieku, Gdańsk 1970; L. Mokrzecki, Studium z dziejów nauczania historii, Gdańsk 1973.

11 L. Mokrzecki, W kręu prac historyków gdańskich XVII wieku, Gdańsk 1974; K. Kubik, L. Mokrzecki, Trzy wieki nauki gdańskiej, Wrocław 1976.

12 K. Kubik, Ksztatcenie morskie w Polsce w XVII i XVIII wieku, "Gdańskie Zeszyty Humanistyczne", R. XIX, 1976, nr 23; L. Mokrzecki, Poczatki wiedzy o morzu w dawnej Rzeczypospolitej, Wrocław 1983.

13 L. Mokrzecki, Rozwazania o kulturze muzycznej miast Prus Królewskich w okresie I Rzeczypospolitej, Zeszyty Naukowe PWSM w Gdańsku, Gdańsk 1976, nr 15; K. Kubik, Wplyw Jana Amosa Komeñskiego na wyksztatcanie sie koncepcji dydaktyczno-wychowawczych na Pomorzu Gdaniskim w XVII w., [w:] Jan Amos Komeński a problemy wspótczesnej pedagogiki, red. L. Leja, Poznań 1974.

14 J. Szews, Język polski w szkolnictwie średnim Pomorza Gdańskiego w latach 1815-1920, Gdańsk 1975; tegoż, Patriotyczne organizacje mtodziezy gimnazjalnej $i$ akademickiej w Gdańsku w latach 1906-1920, „Gdańskie Zeszyty Humanistyczne", R. XX, 1977, nr 24; W. Frackowiak, Pedagogiczne aspekty polskiego czasopiśmiennictwa dla dzieci i modziezy na Pomorzu Nadwiślańskim i Kujawach Zachodnich w okresie rzadów Bismarcka (1862-1890), Bydgoszcz 1979; tegoż. Wydawnictwa z zakresu elementarnej nauki jezyka polskiego na Pomorzu Gdańskim w latach 1840 - 1920, Gdańsk 1977.

15 K. Kubik, Historia szkolnictwa morskiego, Gdańsk 1973.

$16 \mathrm{~K}$. Trzebiatowski, Organizacja szkolnictwa w Polsce Ludowej, Warszawa 1972; tegoż, Poradnik organizacyjno-ekonomiczny dyrektora szkoly. Warszawa 1975; tegoż, System szkolny Szkocji, „Zeszyty Naukowe UG", Pedagogika-Historia Wychowania, 1980, nr 10; K. Trzebiatowski, J. Żerko, System oświatowy PRL na tle porównawczym, Gdańsk 1980. 
17 W kregu kultury, muzyki i baletu, red. L. Mokrzecki, Gdańsk 1971; L. Mokrzecki, Z dziejów Filharmonii Baltyckiej, [w:] Państwowa Opera i Filharmonia Baltycka w Gdanisku, red. B.M. Jankowski, Gdańsk 1971.

18 L. Mokrzecki, Luterańskie gimnazja akademickie w strukturze oświaty okresu staropolskiego, [w:] Nauczanie $w$ dawnych wiekach, red. W. Iwańczak i K. Bracha, Kielce 1997; tegoż, Academical Gymnasiums in Poland in 16th-18th c., [w:] Higher education and society, t. 1, Universidad de Salamanca, Salamanca 1985

19 L. Mokrzecki, K. Puchowski, Contacts between Poland and Hungary in the field of education in XVI-XVIII centuries, ISCHE 9, Pecs 1987; L. Mokrzecki, Academic contacts between Polans, the Grand Duchy of Lithuania, and the Albertina University, [w:] La via dell'ambra, red. R.C. Lewański, Bologna 1994.

20 K. Puchowski, Edukacja historyczna w jezuickich kolegiach Rzeczypospolitej 1565-1773, Gdańsk 1999; tegoż, Nauczanie historii w polskich kolegiach jezuickich 1565-1773, [w:] Jezuici a kultura polska, Kraków 1993; tegoż, Collegium Nobilium Societatis Jesu w Wilnie, [w:] Jezuicka ars educandi, Kraków 1995; L. Mokrzecki, K. Puchowski, Pierwsi nauczyciele historii w szkolnictwie staropolskim, [w:] Nauczyciel historii. Ku nowej formacji dydaktycznej, red. M. Kujawska, Poznań 1996; L. Mokrzecki, Tradycje nauczania historii do końca XVI wieku. Wybrane kraje i problemy, Gdańsk 1992; tegoż, Wokól staropolskiej nauki i oświaty, Gdańsk 2000; J. Taraszkiewicz, Nauczanie historii w szkotach pijarskich prowincji litewskiej w świetle reformy szkolnej z 1762 r., „Kwartalnik Pedagogiczny” t. 40, nr 3, 1995; tegoż. Nauczanie historii $i$ geografii w kolegiach pijarskich w Polsce do 1740 roku, [w:] Wktad pijarów do nauki $i$ kultury $w$ Polsce XVII-XIX w., red. I. Stasiewicz-Jasiukowa, Warszawa - Kraków 1993; K. Puchowski, Edukacja historyczno-geograficzna w kolegiach pijarskich $i$ jezuickich w I Rzeczypospolitej, [w:] Wktad pijarów...; L. Mokrzecki, Uwagi o dziatalności gimnazjów akademickich $i$ kolegiów jezuickich w Prusach Królewskich (XVI-XVIII w.), [w:] Jezuici a kultura polska..

21 L. Mokrzecki, K. Puchowski, Programy szkolnictwa staropolskiego w XVI $i$ XVII wieku. Kierunki zmian, „Kwartalnik Pedagogiczny”, t. 40, 1995, nr 3; K. Puchowski, Model ksztatcenia szlachty w kolegiach jezuickich, [w:] Między Barokiem a Oświeceniem, Olsztyn 1996; tegoż, Jezuickie kolegia szlacheckie Rzeczypospolitej XVIII wieku - źródla i kierunki zmian, ,Kwartalnik Pedagogiczny", t. 40, 1995, nr 3; L. Mokrzecki, Uwagi o wychowaniu $i$ wiedzy wojskowej $w$ oswiacie I Rzeczypospolitej, „Przeglad Humanistyczny”, r. 40, 1996, nr 1; tegoż, Stosunek do nauczania historii w szkolnictwie protestanckim Prus Królewskich (XVI-XVIII w.), „Rozprawy z Dziejów Oświaty”, t. 37, 1996; J. Taraszkiewicz, Józef Kalasancjusz - twórca szkól pijarskich, [w:] Szlakami przeszlości i czasów wspólczesnych, red. K. Puchowski i J. Żerko, Gdańsk 1996; Z dziejów Almae Matris Vilnensis, red. L. Piechnik i K. Puchowski, Krakow 1996.

22 J. Szews, Filomaci Pomorscy, Warszawa 1992; K. Trzebiatowski, Szkolnictwo w województwie pomors- kim w latach 1920 - 1939, Wroclaw 1986; L. Burzyńska, Edukacja dziecka na Kaszubach w XIX i na poczatku XX wieku, Zeszyty Naukowe UG, Pedagogika-Historia Wychowania nr 20, 1992; tejże. Postowie polscy w walce o język polski w Sejmie Pruskim $i w$ parlamencie niemieckim $w$ dobie strajków szkolnych $w$ latach 1906-1907, [w:] Szlakami przeszlości i czasów wspólczesnych...; tejże. Polskie duchowienistwo diecezji chetminiskiej wobec strajków szkolnych w latach 1906-1907 w Prusach Zachodnich, „Rocznik Gdański” t. 57, 1997, z. 2; L. Burzyńska, L. Mokrzecki, K. Puchowski, Die Schule und Integrationsprobleme der pommerischen Jugend im 16. - 19. Jh., [w:] The Polish school system, red. C. Holmberg, W.J. Wojtowicz, Linkôping 1990; L. Mokrzecki, The coming of compulsory education to Poland [w:] A significant social revolution, red. J.A. Mangan, London 1994.

23 L. Mokrzecki, The universities in Poland in the first half of 19th century, [w:] Le Universita minori in Europa (secoli $X V-X I X$ ), red. G.P. Brizzi i J. Verger, Catanzaro 1998.

24 Oświata $i$ wychowanie $w$ województwie gdaniskim w okresie 40-lecia, Gdańsk 1986. Bibliografię gdańskiej historii wychowania zawieraja m.in. prace: J. Szews, Bibliografia historii oświaty..., „Przegląd Historyczno-Oswiatowy" 1964 , nr 2; 1968, nr 2; $1976 \mathrm{nr} 4$; K. Puchowski, Z problematyki badań..., ,Zeszyty Naukowe UG", Pedagogika-Historia Wychowania nr 17, 1988; R. Grzybowski, State and research on the history of science and education in the Gdanisk Region of Pomerania in 19:h and 20 century, "Rocznik Gdański” 1990, t. 50, z. 1, tegoż Obecność historyków wychowania II Rzeczypospolitej w pedagogice polskiej 1945-1956 (na tle głównych kierunków badań historii wychowania), [w:] Historycy wychowania II Rzeczypospolitej, pod red. W. Szulakiewicz, Warszawa 2000. Dorobek K. Kubika zebrano [w:] Zeszyty Naukowe UG, Pedagogika - Historia Wychowania nr 10, 1980 i nr 17, 1988 oraz „Rocznik Gdański”, t. 56, 1996, z. 2; publikacje K. Trzebiatowskiego [w:] Zeszyty Naukowe UG, Pedagogika-Historia Wychowania nr 13, 1983 i nr 21, 1993 zaś L. Mokrzeckiego do 1995 r., [w:] Szlakami przeszlosici i czasów wspólczesnych, Gdańsk 1996 i do 2000 r. [w:] L. Mokrzecki, Wokót staropolskiej nauki i oświaty. Gdańsk - Prusy Królewskie - Rzeczpospolita, Gdańsk 2000. Zob. też Stownik biograficzny Pomorza Nadwiślańskiego, t. I-IV, Gdańsk 1992 - 1997; Stownik Pedagogów Polskich, red. W. Bobrowska-Nowak, D. Drynda, Katowice 1998; Wspótcześni uczeni polscy, t. I-III, Warszawa 2000; Zlota ksiega nauki polskiej. Naukowcy przelomu wieków, Gliwice 2000; The International Direclory of Distinghished Leadership, Raleigh, North Carolina 2000; Dictionary of International Biography, Cambridge, England 1995; International Who's Who of Intellectuals, Cambridge, England 1993; Scholars of Early Modern Studies. Annual Directory of Research, vol. 27-34, Truman State University, Kirksville, Missouri USA, $1993-2000$.

25 J. Żerko, Szkolnictwo ogólnoksztatcace dla pracujacych $w$ województwie gdańskim $w$ latach 1945-1975, Wrocław 1986; tegoż, Etapy zwalczania analfabetyzmu w województwie gdaniskim (1945 - 1952), 
„Rocznik Gdański” t. 47, 1987, z. 2; J. Żerko, R. Grzybowski, Realizacja obowiazku szkolnego w okresie międzywojennym, „Zeszyty Naukowe UG”, Pedagogika-Historia Wychowania, nr 17, 1988; R. Grzybowski, Studia nauczycielskie $w$ województwie gdańskim $w$ la. tach 1955 - 1970, Gdańsk 1994; tegoż, Przebudowa ideowa zaktadów ksztatcenia nauczycieli w Polsce $w$ latach 1945 - 1956, „Kwartalnik Pedagogiczny” t. 40, 1995, z. 4 ; J. Siwoszko, $Z$ badan nad organizacja i funkcjonowaniem gdaniskich szkól niepaństwowych, [w:] Oświata w okresie przemian ustrojowych w Polsce, Gdańsk 1995; J. Siwoszko, J. Żerko, Oświatowa kadra kierownicza $i$ jej przygotowanie zawodowe w Polsce w latach 1945 - 1990, ,Zeszyty Naukowe UG", Pedagogika-Historia Wychowania, nr 25,1997; L. Mokrzecki, 40 lat Państwowej Szkoty Muzycznej stopnia podstawowego i licealnego im. Feliksa Nowowiejskiego w Gdanisku (1950-1990), [w:] Państwowa Szkota Muzyczna stopnia podstawowego i licealnego im. F. Nowowiejskiego w Gdanisku 1950-1990, red. J. Krassowski, Gdańsk 1990; R. Grzybowski. Wyzisze szkoly pedagogiczne w Polsce w latach 1946-1956, Gdańsk 2000.

${ }_{26} S(z)$ koldem project papers. Democratization of education experiences from Poland and Sweden, red. $\mathrm{H}$. Hovenberg, T. Maliszewski, W.J. Wojtowicz, J. Żerko, Linkoping 1996; T. Maliszewski, Polacy a szwedzki uniwersytet ludowy, [w:] Polacy w Skandynawii, red. E. Olszewski, Lublin 1997; tegoż, Folk High Schools - the End of an Idea or a new Challenge, „Baltic Sea Dialogue" 1998, Nr 1; tegoż, Od światlej wlościanki do radykalnej feministki. Kobieta w szwedzkim uniwersytecie ludowym [w:] Kobiety a edukacja dorostych, red. E. A. Wesołowska, Warszawa 2001, tegoż, Historia i kierunki działalności edukacyjnej Kaszubskiego Uniwersytetu Ludowego, „Rocznik Andragogiczny" 1999; L. Mokrzecki, J. Żerko, Problematyka demokratyzacji oświaty $w$ regionie gdańskim w świetle badań polsko-szwedzkich pod nazwa "S(z)koldem" (1993-1996), [w:] Wychowanie a polityka. Tradycje i wspótczesność, red. W. Wojdyło i M. Strzelecki, Toruń 1997. Znaczenie wspólnych badań potwierdza przyznanie w $1998 \mathrm{r}$. przez Uniwersytet w Linkóping doktoratu h.c. profesorowi L. Mokrzeckiemu.

27 Por. sprawozdania $\mathrm{z}$ sesji: E. Romanowska, Sprawozdanie $z$ jubileuszu profesora Uniwersytetu Gdanskiego Lecha Mariana Mokrzeckiego, Komunikat z Ogólnopolskiej Konferencji Naukowej na temat "Historia-Edukacja” Gdańsk-Oliwa 20 maja 1996 r. „Test” nr 2, Białystok 1996; B. Michalik, Ogólnopolska Konferencja Historyków Wychowania "Historia-Edukacja", Gdańsk 20 maja 1996, „,Rozprawy z dziejów oświaty", t. XXXVIII, 1998; T. Maliszewski, ,Historia i Edukacja” - Ogólnopolska Konferencja Historyków i Historyków Oświaty z okazji jubileuszu prof. dr hab. Lecha Mokrzeckiego, „Rocznik Gdański”, t. 47, 1997. Por. Ars Educandi, t. I (1998). Również wydawnictwo okolicznościowe zatytułowane Szlakami przeszlości i czasów wspótczesnych. Ksiega ofiarowana profesorowi Lechowi Mokreckiemu z okazji Jego jubileuszu, pod red. K. Puchowskiego i J. Żerko, Gdańsk 1996, doczekała się recenzji („Rocznik Gdański”, „Biuletyn Historii Wychowania” (Poznań), „Lubelski Rocznik Pedagogiczny”, „Rozprawy z Dziejów Oswiaty" (Warszawa) i in.

28 Liczne przemyślenja polskich uczonych prezentowane na zagranicznych konferencjach zawieraja kolejne tomy publikowane $w$ ramach International Standing Conference for the History of Education, w znanym periodyku „Paedagogica Historica”, czy osobnych wydawnictwach, zaś informacje o nich, poza bibliografiami, znajduja się w licznych tomach „Nauki Polskiej”, „Lubelskiego Rocznika Pedagogicznego" ,'Rocznika Gdańskiego" oraz Przeglądu Historyczno-Oświatowego. 